Genij Ortopedii. 2021. Vol. 27, no. 6. P. 740-745.

Original article

https://doi.org/10.18019/1028-4427-2021-27-6-740-745

\title{
Comparison of the main risk factors for sepsis in patients with non-specific osteomyelitis of the spine and tuberculous spondylitis
}

\begin{abstract}
Arkadii A. Vishnevskii
St. Petersburg Research Institute of Phthisiopulmonology, Saint Petersburg, Russian Federation, vichnevsky@mail.ru, https://orcid.org/0000-0002-9186-6461

\section{Abstract}

Background Chronic osteomyelitis is characterized by changes in bone structure of different extent and severity that are poorly defined. The objective was to determine the incidence of sepsis in patients with non-specific osteomyelitis of the spine (NOS) and tuberculous spondylitis (TS), and compare the main risk factors contributing to the occurrence. Material and methods Treatment was produced for 82 patients with verified sepsis that accounted for $8.6 \%$ of all patients operated for infectious spondylitis (IS). Patients were diagnosed with NOS $(n=48$, Group 1) and TS $(n=34$, Group 2). Microflora in the blood was detected in half ( $n=39$, $47.5 \%$ ) of the patients with procalcitonin test performed in all cases. Results IS patients were diagnosed with chronic pulmonary diseases (45/58.0 \%), renal diseases (32/39.0 \%), chronic stomach and duodenal diseases (23/28.0\%), viral hepatitis (18/21.9\%), cardiovascular diseases (23/28.0 \%), diabetes mellitus (12/14.6\%), etc. Factors contributing to the development of sepsis in TS patients were chronic pulmonary diseases $\left(p=0.024, \chi^{2}=7.132\right)$, liver cirrhosis $\left(p=0.036, \chi^{2}=6.458\right)$ and HIV $\left(p=0.035, \chi^{2}=6.158\right)$. Discussion Risk factors for septic conditions in IS patients included age over 70 years, severe neurological deficit, hypoalbuminemia, cachexia $\left(\mathrm{BMI}<17 \mathrm{~kg} / \mathrm{m}^{2}\right)$, obesity $\left(\mathrm{BMI}>35 \mathrm{~kg} / \mathrm{m}^{2}\right)$, HIV and severe comorbidities (ASA 3 or ASA 4 ). The favorable outcome of the disease occurred due to early detection of sepsis based on SOFA score and timely initiated pathogenetic treatment.

Keyword: infectious spondylitis, non-specific osteomyelitis of spine, tuberculous spondylitis, HIV, risk factors
\end{abstract}

For citation: Vishnevskii A.A. Comparison of the main risk factors for sepsis in patients with non-specific osteomyelitis of the spine and tuberculous spondylitis. Genij Ortopedii, 2021, vol. 27, no 6, pp. 740-745. https://doi.org/10.18019/1028-4427-2021-27-6-740-745.

\section{INTRODUCTION}

Sepsis is a recognized global health challenge and associated with high morbidity and mortality $[1,2]$. The incidence of sepsis and septic shock after elective interventions ranges from 1 to $2.1 \%$ [2]. Despite advancements in therapy, mortality rate is 1.9-17 \% [3,4]. Intensive care costs for a sepsis patient are 4-6 times higher than treatment compared with other ICU patients $[5,6]$. Surgical treatment of infectious spondylitis (IS) is associated with the risk of postoperative complications that range between $6 \%$ and $30 \%$ [7-9] and can be classified as early, delayed and late infections [10]. Sepsis can be caused by surgical site infection (SSI), nosocomial pneumonia, catheter related bacteremia and urinary tract infection [11-13].

The reported risk factors include old age, severe neurological deficit, alimentary disorders, ASA 3 and ASA 4, etc. [14-18]. In recent years, the incidence of IS has steadily risen in immunocompromised patients who often develop early infectious and septic complications [19].
Postoperative complications (generalized infection and meningoencephalitis) are 8 times more common and postoperative mortality rate being 1.5 times higher in HIV-positive patients with tuberculous spondylitis (TS) than in HIV-negative patients [19].

A link between age, concomitant diseases and the development of sepsis in patients with emergency surgical pathology is described in large epidemiological studies $[5,20]$. R. Sobottke (2010) reported the complication rate being almost twice as high in treatment of IS in patients aged $>$ or $=65$ years $(40.6 \%$ ) [20]. However, most studies focus on retrospective case series included in large databases that are not aimed at studying the factors for sepsis in patients operated on for IS.

The objective was to determine the incidence of sepsis in patients with non-specific osteomyelitis of the spine (NOS) and tuberculous spondylitis (TS), and compare the main risk factors contributing to the occurrence.

\section{MATERIAL AND METHODS}

A prospective cohort study included 952 histories of patients (560 TS and 392 NOS) treated in the Intensive Care Unit (ICU) of the St. Petersburg Research Institute of Phthisiopulmonology, the Ministry of Health of Russia between 2015 and 2019. The study cohort consisted of 82 patients with verified sepsis, patients' age ranged from 23 to 82 years $(\mathrm{M} \pm \mathrm{m}, 49 \pm 13$ years; $\mathrm{Me}, 46$ years $)$. NOS was diagnosed in 48 patients (26 males and 22 female, group 1), and 34 (16 men and 18 women, group 2) had TS. Eighteen $(21.9 \%)$ had sepsis on admission, and 64 patients $(79.1 \%)$ developed sepsis postoperatively. Septic condition was identified in accordance with the criteria of the Surviving sepsis campaign (SSC) [21-24]. Upon admission to the ICU, the patient's condition was assessed by SOFA [21-23]. The level of procalcitonin (PCT) was determined using the PCTVQQ test system (BRAHMS AG,

(c) Vishnevskii A.A., 2021 
Germany). Blood PCT of $2 \mathrm{ng} / \mathrm{mL}$ to $10 \mathrm{ng} / \mathrm{mL}$ indicated to sepsis. Severity of changes in laboratory markers of inflammation (CRP, ESR, leukocyte formula) was explored in dynamics. Systemic inflammatory response (SIR) was identified with $\mathrm{C}$-reactive protein (CRP) level (normal limits $0-6 \mathrm{~g} / \mathrm{L}$ ). There were 3 subgroups based on ranking SIR according to the severity of IC [25] with $\mathrm{CRP}<50 \mathrm{~g} / \mathrm{L}$ denoting a light condition (28/34.1\%), CRP of 51 to 150 $\mathrm{g} / \mathrm{L}$ moderate $(34 / 41.5 \%)$ and $>150 \mathrm{~g} / \mathrm{L}$ a severe course of the disease $(10 / 12.2 \%)$, with no significant difference found between TS and NOS (Table 1).

Table 1

CRP measured in NOS (group 1) and TS (group 2) patients

\begin{tabular}{|c|c|c|c|}
\hline CRP $(\mathrm{g} / \mathrm{L})$ & Group 1 & Group 2 & $\mathrm{p}$ \\
\hline$<50$ & $38.8 \pm 13.1$ & $35.5 \pm 12.3$ & 0.924 \\
\hline $51-150$ & $77.2 \pm 21.4$ & $72.9 \pm 19.3$ & 0.831 \\
\hline$>150$ & $1858 \pm 23.1$ & $179.4 \pm 22.3$ & 0.789 \\
\hline
\end{tabular}

The patients were divided into subgroups according to the infection localized in cervical spine $9.8 \%$ $(\mathrm{n}=8)$, thoracic spine $34.1 \%(\mathrm{n}=28)$, lumbar spine $43.9 \%(n=36)$, involved two or more levels $12.2 \%$ $(\mathrm{n}=10)$. The extent of the inflammatory process and the number of vertebrae involved were single segmental ( $\mathrm{n}=47 ; 57.3 \%$ ) (1 vertebral motor segment, VMS), polysegmental (two or more VMSs) $(\mathrm{n}=25 ; 30.4 \%)$, multilevel ( $>$ two VMSs separated by an intact segment) $(\mathrm{n}=10 ; 12.2 \%)$. Of 82 patients, $48(58.5 \%)$ had severe neurological disorders AO Spine types A-C. There were $25(30.5 \%)$ HIV positive cases and $8(9.6 \%)$ had a history of oncological diseases. Histological, molecular genetic and/or bacteriological confirmation of TS and NOS was obtained in all patients. Bacteremia was found in $39(47.5 \%)$ IS patients. Polymicrobial etiology was recorded in 64 patients $(78.0 \%$ of cases $)$.

\section{Inclusion criteria:}

- bacteriologically and/or histologically verified IS,

- sepsis confirmed by RCT and meeting SOFA criteria.

The risk of surgery and anesthesia was assessed using the scoring system of the American Association of Anesthesiologists (ASA) and the Charlson Comorbidity Index (CCI). Patients were followed for 2 years. SSI was detected in 8 patients $(9.75 \%)$. The mortality was $9(10.9 \%)$ cases: 4 patients $(4.9 \%$ of the patients treated) died at a short term from progressing sepsis, meningoencephalitis and multiple organ failure. At a long term 3 patients died from drug overdose, 2 from cardiovascular failure and PTE.

Ethical expertise. The study was conducted in accordance with the requirements of the World Medical Association "Ethical principles of conducting scientific medical research with human participation" and "Rules of Clinical Practice in the Russian Federation" approved by Order of the Ministry of Health of the Russian Federation No. 200n dated 01.04.2016.

Statistical analysis was performed using the tools of Windows 10 operating system (MicroSoft Corp., USA) and the Statistica 10.0 program (StatSoft, Inc., USA). The Kolmogorov-Smirnov and Shapiro-Wilk tests were used to investigate quantitative parameters for the normality of the distribution. For all quantitative parameters, the level of bilateral significance was $\mathrm{p}<0.05$ that indicated to the abnormal distribution and therefore the results were presented in the form of $\mathrm{M} \pm \mathrm{m}$ and $\mathrm{Me}$ (min, max). The Mann-Whitney U-test was used to assess the significance of differences in perioperative risk factors, and Pearson's chi-square test was used to evaluate the influence of qualitative parameters on postoperative complications. Effect measures were evaluated using risk ratios (RR).

\section{RESULTS}

Sepsis was detected in 82 cases of our series that accounted for $8.6 \%$ of all operated IS patients. There was no correlation between septic complications and the localization of the lesion and the extent of the spine inflammatory process in the groups $(p>0.05)$. There was also no significant difference in the occurrence of septic conditions in NOS and TS $(p=0.964)$ (Table 2).

Although the groups were comparable by sex there were more NOS patients aged 60 years and

over as compared with TS group (238/42.5\% and $145 / 36.9 \%$, respectively) ( $p=0.064)$. Sepsis was more common in NOS patients than in patients aged 30-60 years $(p=0.377$, OR $=1.34)$ and less than 30 years $(p=0.007, O R=6.32)$. Septic conditions were 5 times more common in TS patients aged 30 60 years $(\mathrm{p}=0.012, \mathrm{OR}=4.62)$ and over 60 years old $(\mathrm{p}=0.009, \mathrm{OR}=4.84)$ than in patients aged under 30 .

Table 2

Age related characteristics of IS patients

\begin{tabular}{|c|c|c|c|c|c|c|c|c|c|}
\hline \multirow{2}{*}{ Age } & \multirow{2}{*}{$\begin{array}{c}\text { Group } 1 \\
\mathrm{n} / \%\end{array}$} & \multicolumn{3}{|c|}{ Sepsis diagnosed } & \multirow{2}{*}{$\begin{array}{c}\text { Group } 2 \\
\mathrm{n} / \%\end{array}$} & \multicolumn{3}{|c|}{ Sepsis diagnosed } & \multirow[b]{2}{*}{$\mathrm{p}$} \\
\hline & & male & female & $\mathrm{n} / \%$ & & male & female & $\mathrm{n} / \%$ & \\
\hline$<30$ & $54 / 9.6$ & 3 & 2 & $5 / 0.9$ & $38 / 9.7$ & 2 & 3 & $5 / 1.3$ & 0.789 \\
\hline $30-60$ & $268 / 47.8$ & 10 & 9 & $19 / 7.1$ & $209 / 53.3$ & 7 & 10 & $17 / 8.1$ & 0.491 \\
\hline$>60$ & $238 / 42.5$ & 13 & 11 & $24 / 10.1$ & $145 / 36.9$ & 7 & 5 & $12 / 8.2$ & 0.064 \\
\hline Total & 560 & 26 & 22 & $48 / 8.5$ & 392 & 16 & 18 & $34 / 8.7$ & 0.964 \\
\hline
\end{tabular}


The premorbidity in IS patients was mostly characterized by somatic diseases and urgent conditions. Major conditions in TS patients contributing to the development of sepsis were chronic lung diseases $\left(\mathrm{p}=0.024, \chi^{2}=7.132\right)$, cirrhosis of the liver $(\mathrm{p}=0.036$, $\left.\chi^{2}=6.458\right)$ and HIV $\left(\mathrm{p}=0.035, \chi^{2}=6.158\right)($ Table 3$)$. Group II included many subjects suffering from HIV, who had tuberculosis and viral hepatitis B and C.

The study showed that the majority of IS patients had a high CCI (more than 6 points). The parameter was strongly associated with risk of surgical intervention according to ASA. $31(88.2 \%)$ TS patients and 2/3 of NOS patients $(30 / 64.5 \%)(p=0.076)$ had a risk of ASA 3 and ASA 4. The difference was determined by the fact that HIV-positive $(\mathrm{n}=16,47.1 \%)$ patients of group 2 had severe concomitant diseases of lung, liver, etc. Comparison of other perioperative risk factors in NOS patients showed a correlation between septic complications and obesity, and TS patients demonstrated correlation between cachexia and low albumin levels (Table 4). There was no correlation between anemia, the severity of neurological disorders and SSI in the groups.

Table 3

Assessment of comorbidity in NOS and TS patients using CCI

\begin{tabular}{|l|c|c|c|c|c|}
\hline \multirow{2}{*}{ Comorbidity } & \multicolumn{2}{c|}{ Group 1 $(\mathrm{n}=48)$} & \multicolumn{2}{c|}{ Group 2 $(\mathrm{n}=34)$} & \multirow{2}{*}{$\mathrm{p}$} \\
\cline { 2 - 5 } & abs. & $\%$ & abs. & $\%$ & \\
\hline Myocardial infarction & 4 & 8.3 & 2 & 5.9 & 0.342 \\
\hline Heart failure & 6 & 12.5 & 3 & 8.8 & 0.143 \\
\hline Peripheral vascular lesion & 2 & 4.1 & 1 & 2.9 & 0.524 \\
\hline Transient acute cerebrovascular disease with residual phenomena & 2 & 4.1 & 3 & 8.8 & 0.376 \\
\hline Dementia & 2 & 4.1 & 2 & 5.9 & 0.724 \\
\hline Bronchial asthma & 2 & 4.1 & 1 & 2.9 & 0.894 \\
\hline Chronic lung diseases & 13 & 27.1 & $32^{*}$ & 94.1 & 0.024 \\
\hline Collagenoses & 2 & 4.1 & 1 & 2.9 & 0.967 \\
\hline Peptic ulcer (stomach or duodenum) & 12 & 25.0 & 11 & 32.3 & 0.997 \\
\hline Cirrhosis of the liver without portal hypertension & 4 & 8.3 & $8 *$ & 23.5 & 0.036 \\
\hline Cirrhosis of the liver with portal hypertension & 2 & 4.1 & 4 & 11.8 & 0.296 \\
\hline Diabetes mellitus & 7 & 14.6 & 5 & 14.7 & 0.756 \\
\hline Acute cerebrovascular disease with plegies & 3 & 6.3 & 4 & 11.8 & 0.412 \\
\hline Chronic renal failure with creatinine levels $>300$ mmol/1 & 3 & 6.3 & 4 & 11.8 & 0.524 \\
\hline Malignant tumors without metastases & 2 & 4.1 & 1 & 2.9 & 0.412 \\
\hline Malignant tumors with metastases & 1 & 2.1 & 1 & 2.9 & 0.825 \\
\hline HIV & 9 & 18.6 & $16 *$ & 47.1 & 0.035 \\
\hline CCI (scores) & $6.5 \pm 1.4$ & $7.4 \pm 1.6$ & 0.235 \\
\hline
\end{tabular}

Table 4

Perioperative risk factors in IS patients of groups 1 and 2

\begin{tabular}{|l|c|c|c|c|}
\hline Risk factors & Group I $(\mathrm{n}=48)$ & Group II $(\mathrm{n}=34)$ & $\mathrm{p}$ & $\chi^{2}$ \\
\hline BMI $>35 \mathrm{~kg} / \mathrm{m}^{2}$ & $12^{*}$ & 5 & 0.047 & 4.761 \\
\hline BMI $<17 \mathrm{~kg} / \mathrm{m}^{2}$ & 5 & $13^{*}$ & 0.029, & 4.395 \\
\hline Albumin level $(<35 \mathrm{~g} / \mathrm{L})$ & 8 & $17^{*}$ & 0.034 & 3.182 \\
\hline Anemia & 36 & 27 & 0.123 & 0.372 \\
\hline SSI & 5 & 3 & 0.318, & 0.974 \\
\hline Neurological disorders (Frenkel types A-C) & 28 & 21 & 0.113 & 0.402 \\
\hline Baseline risk ASA 3 and ASA 4 & 31 & $30^{*}$ & 0.076 & 1.568 \\
\hline
\end{tabular}

Statistical significance of the differences between the qualitative parameters was evaluated using the Pearson criterion $\chi^{2}$, the differences recognized as significant at $\mathrm{p}<0.05^{*}$

\section{DISCUSSION}

The study showed that clinical and laboratory confirmation of sepsis in IS patients was performed in $8.6 \%$ of cases in a specialized spinal department. SIR correlated with the severity of the patient's condition, but there was no significant difference in CRP level of IS patients $(\mathrm{p}>0.05)$. PCT measurement was practical for the sepsis diagnosis and showed no significance for monitoring the effectiveness of IC treatment [26].
Bacteremia was detected in almost half (39/47.5\%) of IS patients. The data were consistent with those published in the Sepsis Guideline (2013) indicating that bacteremia can be detected in $45-48 \%$ of septic patients [27]. It is difficult to identify sepsis, since most patients in the intensive care unit can have several sources of infection. Bacteremia in IS patients can be associated with urinary tract infections, SSI, 
nosocomial pneumonia, peripheral catheters and intestinal dysbiosis [4, 13, 27-29]. Gram(+) bacteremia can be primarily caused by permanent vascular access via catheters and SSI [8, 27]. Although the relationship between sepsis and deep wound infection was obvious there was no significant difference $(p=0.318)$ seen in the groups. Sepsis caused by $\operatorname{gram}(-)$ microflora is more often associated with genitourinary infection and bedsores [13]. There was a correlation observed between septic conditions and premorbidities. Chronic lung diseases $(45 / 58.0 \%)$, kidney diseases $(32 / 39.0 \%)$, chronic stomach and duodenum diseases $(23 / 28.0 \%)$, viral hepatitis $(18 / 21.9 \%)$, cardiovascular diseases $(23 / 28.0 \%)$, diabetes mellitus (12/14.6\%) were common for IC patients among ten concomitant diseases that were identified with CCI. Infectious complications were 1.5 times more common for patients ASA 3 and ASA 4 than for those ASA $2(p=0.021$, OR $=1.68)$.

Risk factors for septic conditions in IS patients $[14,15,17,30]$ include old age, severe neurological deficit, hypoalbuminemia (total protein less than $35 \mathrm{~g} / \mathrm{l}$ ), obesity (BMI > $35 \mathrm{~kg} / \mathrm{m} 2$ ), HIV and severe comorbidities (ASA 3 or ASA 4). Our series showed that old age and obesity in the NOS group and chronic lung, liver diseases and secondary immunodeficiency in TS patients were significant risk factors for infectious complications. Hypoalbuminemia and cachexia could have had a serious effect on outcomes of surgical treatment in group II. V.N. Derbugov et al. (2004) reported severe postoperative complications developing 7 times more common in individuals with a body weight deficit of more than $15 \%$ as compared to patients with normal body weight, and inpatient stay increasing by
1.3-2.4 times [31]. Decreased albumin level in the blood can be one of the reasons of alimentary disorders in IS patients $[32,33]$. Dysproteinemia can also cause pressure sores in patients with compression myelopathy due to spondylitis.

Extensive purulent lesions of the spine, neuralgic disorders and high comorbidity (ASA 3 or ASA 4) can contribute to severe sepsis and multiple organ failure in IS patients. In our series, a pronounced neurological deficit was detected in 49 (59.8\%) patients who also developed polymicrobial microflora isolated in blood, sputum, urinary tract and bedsores. Similar findings were reported by A.Y. Bazarov et al. (2020) [16]. Polymicrobial involvement in combination with concomitant diseases and/or immunodeficiency significantly affects mortality and risk of infectious postoperative complications $[1,9]$.

HIV patients are a specific cohort. There is a correlation reported between the level of CD4+lymphocytes and the incidence of extrapulmonary tuberculosis in HIV-infected individuals $[19,34]$. With a decrease in T-helper cells (CD4+) below 200 cells/mL, tuberculosis often develops in an extrapulmonary form with impaired lymph nodes, pericardium and bones and joints [34]. The majority of HIV-positive patients with IS are often diagnosed with gastrointestinal, cardiovascular diseases, uroinfection, pneumonia. Analysis of CCI and ASA parameters in HIV patients with TS shows a poor prognosis for the life with increased CCI by more than 6 points [19]. E.V. Reshetneva reported [19] a 2-3 fold increased risk of postoperative infectious complications in HIV patients with TS and a specific involvement of the central nervous system $(\mathrm{OR}=8.56)$.

\section{CONCLUSION}

Verified severe sepsis occurred in $8.6 \%$ of patients operated for IS. Early septic complications were shown to be associated with generalized infection or aggravated course of concomitant pathology in IS patients with high comorbidity (ASA 3 or ASA 4). Chronic lung diseases $\left(\mathrm{p}=0.024, \quad \chi^{2}=7.132\right), \quad$ liver cirrhosis $(\mathrm{p}=0.036$, $\left.\chi^{2}=6.458\right)$ and HIV $\left(p=0.035, \chi^{2}=6.158\right)$ were found to be significant factors for sepsis in TS patients. Risk factors for sepsis in IS patients included HIV $(p=0.009$; $\mathrm{OR}=3.18)$, old age $(\mathrm{p}=0.017 ; \quad \mathrm{OR}=2.32)$, severe neurological disorders $(\mathrm{p}=0.019 ; \mathrm{OR}=1.72)$, severe comorbidities ASA 3 or ASA $4(\mathrm{p}=0.021$; OR $=1.68)$. There was correlation between septic complications and old age and obesity (BMI $>35 \mathrm{~kg} / \mathrm{m}^{2}$ ) in NOS patients, and cachexia and low albumin levels were more common for TS patients. These data emphasize the need to identify sepsis by screening in patients with IS based on PCT and SOFA score. Management protocol for IS patients is essential to minimize postoperative complications and mortality recognizing perioperative risk factors.

\section{REFERENCES}

1. Rudnov V.A. Klinicheskie rekomendatsii po diagnostike i lecheniiu tiazhelogo sepsisa i septicheskogo shoka v lechebnoprofilakticheskikh organizatsiiakh Sankt-Peterburga [Clinical guidelines for the diagnosis and treatment of severe sepsis and septic shock in medical institutions of St. Petersburg]. Vestnik Anesteziologii i Reanimatologii, 2016, vol. 13, no. 5, pp. 88-94. (in Russian) DOI: $10.21292 / 2078-5658-2016-13-5-88-94$.

2. Singer M., Deutschman C.S., Seymour C.W., Shankar-Hari M., Annane D., Bauer M., Bellomo R., Bernard G.R., Chiche J.D., Coopersmith C.M., Hotchkiss R.S., Levy M.M., Marshall J.C., Martin G.S., Opal S.M., Rubenfeld G.D., van der Poll T., Vincent J.L., Angus D.C. The Third International Consensus Definitions for Sepsis and Septic Shock (Sepsis-3). JAMA, 2016, vol. 315, no. 8, pp. 801-810. DOI:10.1001/jama.2016.0287.

3. Akiyama T., Chikuda H., Yasunaga H., Horiguchi H., Fushimi K., Saita K. Incidence and risk factors for mortality of vertebral osteomyelitis: a retrospective analysis using the Japanese diagnosis procedure combination database. BMJ Open, 2013, vol. 3, no. 3, pp. e002412. DOI: 10.1136/bmjopen-2012-002412.

4. Kehrer M., Pedersen C., Jensen T.G., Hallas J., Lassen A.T. Increased short- and long-term mortality among patients with 
infectious spondylodiscitis compared with a reference population. Spine J., 2015, vol. 15, no. 6, pp. 1233-1240. DOI: 10.1016/j. spinee.2015.02.021.

5. Angus D.C., Linde-Zwirble W.T., Lidicker J., Clermont G., Carcillo J., Pinsky M.R. Epidemiology of severe sepsis in the United States: analysis of incidence, outcome, and associated costs of care. Crit. Care Med., 2001, vol. 29, no. 7, pp. $1303-1310$. DOI: 10.1097/00003246-200107000-00002.

6. Blumberg T.J., Woelber E., Bellabarba C., Bransford R., Spina N. Predictors of increased cost and length of stay in the treatment of postoperative spine surgical site infection. Spine J., 2018, vol. 18, no. 2, pp. 300-306. DOI: 10.1016/j.spinee. 2017.07.173.

7. Berbari E.F., Kanj S.S., Kowalski T.J., Darouiche R.O., Widmer A.F., Schmitt S.K., Hendershot E.F., Holtom P.D., Huddleston P.M. 3 $3^{\text {rd }}$, Petermann G.W., Osmon D.R., Infectious Diseases Society of America. 2015 Infectious Diseases Society of America (IDSA) Clinical Practice Guidelines for the Diagnosis and Treatment of Native Vertebral Osteomyelitis in Adults. Clin. Infect. Dis., 2015, vol. 61, no. 6, pp. P. e26-e46. DOI: 10.1093/cid/civ482.

8. Nota S.P., Braun Y., Ring D., Schwab J.H. Incidence of surgical site infection after spine surgery: what is the impact of the definition of infection? Clin. Orthop. Relat. Res., 2015, vol. 473, no. 5, pp. 1612-1619. DOI: 10.1007/s11999-014-3933-y.

9. Liu Y., Li Y., Miao J. Wound drains in posterior spinal surgery: a meta-analysis. J. Orthop. Surg. Res., 2016, vol. 11, pp. 16. DOI: 10.1186/s13018-016-0351-8.

10.Dowdell J., Brochin R., Kim J., Overley S., Oren J., Freedman B., Cho S. Postoperative Spine Infection: Diagnosis and Management. Global Spine J., 2018, vol. 8, no. 4 Suppl., pp. 37S-43S. DOI: 10.1177/2192568217745512.

11.Schimmel J.J., Horsting P.P., de Kleuver M., Wonders G., van Limbeek J. Risk factors for deep surgical site infections after spinal fusion. Eur. Spine J., 2010, vol. 19, no. 10, pp. 1711-1719. DOI: 10.1007/s00586-010-1421-y.

12.Dubory A., Giorgi H., Walter A., Bouyer B., Vassal M., Zairi F., Dhenin A., Grelat M., Lonjon N., Dauzac C., Lonjon G. Surgicalsite infection in spinal injury: incidence and risk factors in a prospective cohort of 518 patients. Eur. Spine J., 2015, vol. 24, no. 3, pp. 543-554. DOI: 10.1007/s00586-014-3523-4.

13.Chenoweth C.E., Saint S. Urinary Tract Infections. Infect. Dis. Clin. North Am., 2016, vol. 30, no. 4, pp. 869-885. DOI: 10.1016/j. idc.2016.07.007.

14.Kang S.J., Jang H.C., Jung S.I., Choe P.G., Park W.B., Kim C.J., Song K.H., Kim E.S., Kim H.B., Oh M.D., Kim N.J., Park K.H. Clinical characteristics and risk factors of pyogenic spondylitis caused by gram-negative bacteria. PLoS One, 2015, vol. 10, no. 5, pp. e0127126. DOI: 10.1371/journal.pone.0127126.

15.Nasser R., Kosty J.A., Shah S., Wang J., Cheng J. Risk Factors and Prevention of Surgical Site Infections Following Spinal Procedures. Global Spine J., 2018, vol. 8, no. 4 Suppl., pp. 44S-48S. DOI: 10.1177/2192568218806275.

16.Bazarov A.Iu., Lebedev I.A., Barinov A.L., Rebiatnikova M.A., Farion A.O., Paskov R.V., Sergeev K.S., Osintsev V.M. Gematogennyi osteomielit pozvonochnika: klinicheskaia i mikrobiologicheskaia kharakteristika [Hematogenous osteomyelitis of the spine: clinical and microbiological characteristics]. Khirurgiia Pozvonochnika, 2020. t. 17, № 1. c. 102-109. (in Russian) DOI: 10.14531/ss2020.1.102-109.

17.Vishnevskii A.A. Septicheskie sostoianiia pri infektsionnykh spondilitakh: faktory riska i diagnostika [Septic conditions in infectious spondylitis: risk factors and diagnosis]. Materialy VIII Kongressa Natsionalnoi Assotsiatsii Ftiziatrov (Sankt-Peterburg, 25-27 Noiabria 2019) [Proceedings of the VIII Congress of National Association of Phthisiologists (St. Petersburg, November 25-27, 2019)]. SPb., 2019, pp. 64-66. (in Russian)

18.Oganov R.G., Denisov I.N., Simanenkov V.I., Bakulin I.G., Zakharova N.V., Boldueva S.A., Barbarash O.L., Garganeeva N.P., Doshchitsin V.L., Drapkina O.M., Dudinskaia E.N., Kotovskaia Iu.V., Lila A.M., Mamedov M.N.O., Mardanov B.U., Miller O.N., Petrova M.M., Pozdniakov Iu.M., Runikhina N.K., Saiganov S.A., Tarasov A.V., Tkacheva O.N., Urinskii A.M., Shalnova S.A. Komorbidnaia patologiia v klinicheskoi praktike. Klinicheskie rekomendatsii [Comorbid pathology in clinical practice. Clinical guidelines]. Kardiovaskuliarnaia Terapiia i Profilaktika, 2017, vol. 16, no. 6, 52 p. (in Russian) DOI: 10.15829/1728-8800-20176-5-56.

19.Reshetneva E.V., Mushkin A.Iu., Zimina V.N. Analiz riskov posleoperatsionnykh oslozhnenii u patsientov tuberkuleznym spondilitom pri soputstvuiushchei VICH-infektsii [Analysis of the risks of postoperative complications in patients with tuberculous spondylitis with concomitant HIV infection]. Tuberkulez i Bolezni Legkikh, 2015, no. 4, pp. 36-41. (in Russian) DOI: 10.21292/20751230-2015-0-4-36-41.

20.Sobottke R., Röllinghoff M., Zarghooni K., Zarghooni K., Schlüter-Brust K., Delank K.S., Seifert H., Zweig T., Eysel P. Spondylodiscitis in the elderly patient: clinical mid-term results and quality of life. Arch. Orthop. Trauma Surg., 2010, vol. 130, no. 9, pp. 1083-1091. DOI: 10.1007/s00402-009-0972-z.

21.Seymour C.W., Liu V.X., Iwashyna T.J., Brunkhorst F.M., Rea T.D., Scherag A., Rubenfeld G., Kahn J.M., Shankar-Hari M., Singer M., Deutschman C.S., Escobar G.J., Angus D.C. Assessment of Clinical Criteria for Sepsis: For the Third International Consensus Definitions for Sepsis and Septic Shock (Sepsis-3). JAMA, 2016, vol. 315, no. 8, pp. 762-774. DOI: 10.1001/jama.2016.0288.

22.Rhodes A., Evans L.E., Alhazzani W., Levy M.M., Antonelli M., Ferrer R., Kumar A., Sevransky J.E., Sprung C.L., Nunnally M.E., Rochwerg B., Rubenfeld G.D., Angus D.C., Annane D., Beale R.J., Bellinghan G.J., Bernard G.R., Chiche J.D., Coopersmith C., de Backer D.P., French C.J., Fujishima S., Gerlach H., Hidalgo J.L., Hollenberg S.M., Jones A.E., Karnad D.R., Kleinpell R.M., Koh Y., Lisboa T.C., Machado F.R., Marini J.J., Marshall J.C., Mazuski J.E., McIntyre L.A., McLean A.S., Mehta S., Moreno R.P., Myburgh J., Navalesi P., Nishida O., Osborn T.M., Perner A., Plunkett C.M., Ranieri M., Schorr C.A., Seckel M.A., Seymour C.W., Shieh L., Shukri K.A., Simpson S.Q., Singer M., Thompson B.T., Townsend S.R., van der Poll T., Vincent J.L., Wiersinga W.J., Zimmerman J.L., Dellinger R.P. Surviving Sepsis Campaign: International Guidelines for Management of Sepsis and Septic Shock: 2016. Intensive Care Med., 2017, vol. 43, no. 3, pp. 304-377. DOI: 10.1007/s00134-017-4683-6.

23.Simpson S.Q. SIRS in the time of Sepsis-3. Chest, 2018, vol. 153, no. 1, pp. 34-38. DOI: 10.1016/j.chest.2017.10.006.

24.Astafeva M.N., Rudnov V.A., Kulabukhov V.V., Bagin V.A., Zubareva N.A., Tribulev M.A., Mukhacheva S.Iu. Ispolzovanie shkaly qSOFA v prognoze iskhoda u patsientov s sepsisom v ORIT (rezultaty Rossiiskogo Mnogotsentrovogo Issledovaniia RISES) [Use of the qSOFA scale in the prognosis of outcome in patients with sepsis in the Department of Resuscitation and Intensive Therapy (results of RISES Russian Multicenter Study)]. Vestnik Anesteziologii i Reanimatologii, 2018, vol. 15, no. 5, pp. 22-29. (in Russian) DOI: 10.21292/2078-5658-2018-15-5-22-29. 
25.Homagk L., Marmelstein D., Homagk N., Hofmann G.O. SponDT (Spondylodiscitis Diagnosis and Treatment): spondylodiscitis scoring system. J. Orthop. Surg. Res., 2019, vol. 14, no. 1, pp. 100. DOI: 10.1186/s13018-019-1134-9.

26.Jeong D.K., Lee H.W., Kwon Y.M. Clinical Value of Procalcitonin in Patients with Spinal Infection. J. Korean Neurosurg. Soc., 2015, vol. 58, no. 3, pp. 271-275. DOI: 10.3340/jkns.2015.58.3.271.

27.Dellinger R.P., Levy M.M., Rhodes A., Annane D., Gerlach H., Opal S.M., Sevransky J.E., Sprung C.L., Douglas I.S., Jaeschke R., Osborn T.M., Nunnally M.E., Townsend S.R., Reinhart K., Kleinpell R.M., Angus D.C., Deutschman C.S., Machado F.R., Rubenfeld G.D., Webb S.A., Beale R.J., Vincent J.L., Moreno R.; Surviving Sepsis Campaign Guidelines Committee including the Pediatric Subgroup. Surviving sepsis campaign: international guidelines for management of severe sepsis and septic shock: 2012. Crit. Care Med., 2013, vol. 41, no. 2, pp. 580-637. DOI: 10.1097/CCM.0b013e31827e83af.

28.Anderson P.A., Savage J.W., Vaccaro A.R., Radcliff K., Arnold P.M., Lawrence B.D., Shamji M.F. Prevention of surgical site infection in spine surgery. Neurosurgery, 2017, vol. 80, no. 3S, pp. S114-S123. DOI: 10.1093/neuros/nyw066.

29.Vishnevskii A.A., Soloveva N.S. Mikrobiologicheskii spektr nozokomialnoi infektsii u bolnykh s infektsionnymi spondilitami, perenesshikh sepsis [Microbiological spectrum of nosocomial infection in patients with infectious spondylitis who underwent sepsis]. Zhurnal Infektologii, 2019, vol. 11, no. 4, pp. 134-141. (in Russian) DOI: 10.22625/2072-6732-2019-11-4-134-141.

30.Whitmore R.G., Stephen J., Stein S.C., Campbell P.G., Yadla S., Harrop J.S., Sharan A.D., Maltenfort M.G., Ratliff J.K. Patient comorbidities and complications after spinal surgery: a societal-based cost analysis. Spine (Phila Pa 1976), 2012, vol. 37, no. 12, pp. 1065-1071. DOI: 10.1097/BRS.0b013e31823da22d.

31.Derbugov V.N., Sloventantor V.Iu., Khmelevskii Ia.M. Komponenty sostava tela bolnykh rakom zheludka (vliianie stadii zabolevaniia i nutritivnoi podderzhki po rezultatam issledovaniia bioimpedansa tela). Vestnik Intensivnoi Terapii, 2004, no. 2, pp. 36-40. (in Russian)

32.Bohl D.D., Shen M.R., Mayo B.C., Massel D.H., Long W.W., Modi K.D., Basques B.A., Singh K. Malnutrition Predicts Infectious and Wound Complications Following Posterior Lumbar Spinal Fusion. Spine (Phila Pa 1976), 2016, vol. 41, no. 21, pp. $1693-1699$. DOI: 10.1097/brs.0000000000001591.

33.Khanna K., Yi P.H., Sing D.C., Geiger E., Metz L.N. Hypoalbuminemia is associated with septic revisions after primary surgery and postoperative infection after revision surgery. Spine (Phila Pa 1976), 2018, vol. 43, no. 6, pp. 454-460. DOI:10.1097/ brs.0000000000002436.

34.Jaryal A., Raina R., Sarkar M., Sharma A. Manifestations of tuberculosis in HIV/AIDS patients and its relationship with CD4 count. Lung India, 2011, vol. 28, no. 4, pp. 263-266. DOI: 10.4103/0970-2113.85687.

The article was submitted 25.05.2021; approved after reviewing 12.07.2020; accepted for publication 19.10.2021.

\section{Information about the author:}

Arkadii A. Vishnevskii - Doctor of Medical Sciences. 